The Contribution of "Shared Education" to Catholic-Protestant Reconciliation in Northern Ireland: A Third Way?

\author{
Vani K. Borooah and Colin Knox
}

University of Ulster

British Educational Research Journal Vol 39 (5) 2013: 925-946

Contact details:

Vani K Borooah

School of Economics

University of Ulster

Shore Road

Jordanstown

Northern Ireland

BT 37 OQB

Email: vk.borooah@ulster.ac.uk

Tel: +44 (0)2890366934
Colin Knox

School of Criminology, Politics and Social Policy

University of Ulster

Shore Road

Jordanstown

Northern Ireland

BT 37 OQB

Email: cg.knox@ulster.ac.uk

Telephone: +44 (0)2890366667

Acknowledgements: The authors kindly acknowledge the inputs to this research from Shared Education Project staff, teachers and participating pupils. Any errors remain are the sole responsibility of the authors. 


\title{
The Contribution of "Shared Education" to Catholic-Protestant Reconciliation in Northern Ireland: A Third Way?
}

\begin{abstract}
Northern Ireland has achieved political stability and its devolved government is now tackling public policy issues neglected during periods of sectarian violence. Notwithstanding the prevailing political optimism, one legacy of the conflict is a deeply divided society. This is particularly manifest in the education system where around $90 \%$ of children attend either state (Controlled) schools (de facto Protestant) or Catholic (Maintained) schools, with integrated schools accounting for less than $6 \%$ of the school population. In an attempt to address this wasteful duplication of services, external funders have piloted an initiative entitled The Shared Education Programme (SEP) where schools working in cross-community partnerships deliver shared classes and activities in order to improve education outcomes. This paper attempts to: quantify the educational returns for pupils participating in the SEP; articulate the qualitative reconciliation benefits from the perspective of teachers, parents and pupils; and, locate the findings of the research in the ongoing policy debate about restructuring education provision in Northern Ireland at a time of budget retrenchment and declining school rolls.
\end{abstract}

Keywords: shared education; Northern Ireland; economic benefits.

\section{Introduction}

Northern Ireland is witnessing an ongoing period of stability with the five main political parties working as a power sharing coalition in a devolved government at Stormont. Alongside these political developments described by the First Minister, Peter Robinson, as the 'most settled period of devolution for over forty years' (2009:2), there has been a significant reduction in violence. While this paints an optimistic picture which should not be understated, the conflict has left a legacy of segregation and division at the community level. Northern Ireland remains a deeply divided society. More than $70 \%$ of social housing estates are $90 \%$ single identity occupied and interface barriers between communities (so called 'peace' walls) have increased in number. In the Belfast area alone, there are 83 
security and segregation barriers (Community Relations Council, 2009). The devolved government has acknowledged the problems of a divided society and launched a consultation document entitled Programme for Cohesion, Sharing and Integration (2010) setting out the Northern Ireland Executive's vision for the future by challenging the assumption that division and segregation is a 'normal' pattern of living (Knox, 2011). The document commits to reducing and eventually eliminating segregated services (OFMdFM, 2010: 1).

Perhaps the starkest manifestation of a divided society is to be found in the education system where around $90 \%$ of children attend either state Controlled (de facto Protestant) or Catholic (Maintained) schools. During the school year 2010/11 some 321,700 pupils attended nursery, primary, post-primary and special schools in Northern Ireland. Less than half of these pupils $(152,300)$ attended primary schools in which Controlled schools' population contained $0.53 \%$ Catholic children and Maintained schools $1.07 \%$ Protestants (Department of Education, 2011a). The statistics illustrate just how polarised Northern Ireland is, with integrated education accounting for less than $6 \%$ of the school population.

Yet the potential for education to contribute to a shared future was highlighted in an independent review of education (the Bain Report) set up to examine strategic planning, funding and organisation of the schools estate in light of declining schools rolls (Bain, 2006). The review argued that the rationale for integrating education, improved collaboration and sharing rested on three fundamental and inter-related factors: pupils would have access to wider curriculum choices, high quality teaching and facilities; the promotion of tolerance, mutual understanding and inter-relationship through regular engagement amongst pupils; and, cost-effective provision - educational, social and economic arguments, respectively.

The debate on tackling duplication in education has assumed greater urgency with recent pressures to reduce public expenditure and an announcement by the First Minister that he regarded the education in Northern Ireland as a 'benign form of apartheid which was fundamentally damaging to our society' and supported a single unified system (Robinson, 2011:1). There is however little evidence of the Department of Education fully embracing this aspiration thus far. In a recent policy document on schools, the Department cut the 
amount of funding available for the promotion of equality and good community relations among children from $£ 3.6 \mathrm{~m}$ to $£ 1.1 \mathrm{~m}$ and limits the activities it will support to personnel training and the dissemination of good practice materials (Department of Education, 2011b).

Previous research (Gallagher, 2004; Brocklehurst, 2006; Hayes \& McAlister 2009; Hughes, 2011) has indicated the problems associated with separate sectoral schools in Northern Ireland and the long-term effect on social attitudes. As Brocklehurst (2006: 92) notes:

The [separate] school is essentially a closed environment where potent sentiments expressed between children can ramify their notions of religious difference, and physical bullying and peer pressure can reinforce concepts of identity (cited in Hughes, Donnelly, Gallagher and Carlisle, 2010).

The lack of significant growth in the integrated sector and the ongoing control which churches exert in protecting single identity education prompted external funders (Atlantic Philanthropies and the International Fund for Ireland) to support an initiative entitled the Shared Education Programme (SEP). In 2007 they funded a three year programme of 12 partnerships comprising 60 schools in Northern Ireland which collaborated on a crosscommunity basis to share classes and activities in order to improve education outcomes for pupils (Gallagher et al, 2010). The external funders extended the range of providers and duration of the programme for a further three years and at present there are around 150 schools involving $10,500+$ pupils in shared education (from a total school population of 322,000 approximately) ${ }^{1}$.

The underpinning model (see figure 1 ) involves cross-community collaboration based on sustained contact between pupils in the delivery of the curriculum in schools (Donnelly and Hughes, 2006; Hughes, 2007). The intention, unlike previous community relations initiatives in schools, is not to see joint activities as one-off extra-curricular events but rather to put cross-community working at the heart of the process via the joint delivery of elements of the curriculum. Through collaboration, interdependencies develop across traditional school boundaries in a way which is non-threatening. As a consequence, these boundaries become

\footnotetext{
${ }^{1}$ The 3 providers are Queen's University, School of Education; The Fermanagh Trust; and the North Eastern Education and Library Board - Primary Integrating/Enriching Education Project.
} 
more porous and the distinctions which underpin existing structures are less relevant. Creating interdependencies demands rethinking the current system of autonomous school units with delegated budgets, whose success is based on competition for pupils. Rather a networked approach is established offering mutual cross-community support. Parents endorse such collaboration because it improves the quality of their children's education, and who the provider is, becomes less important to them.

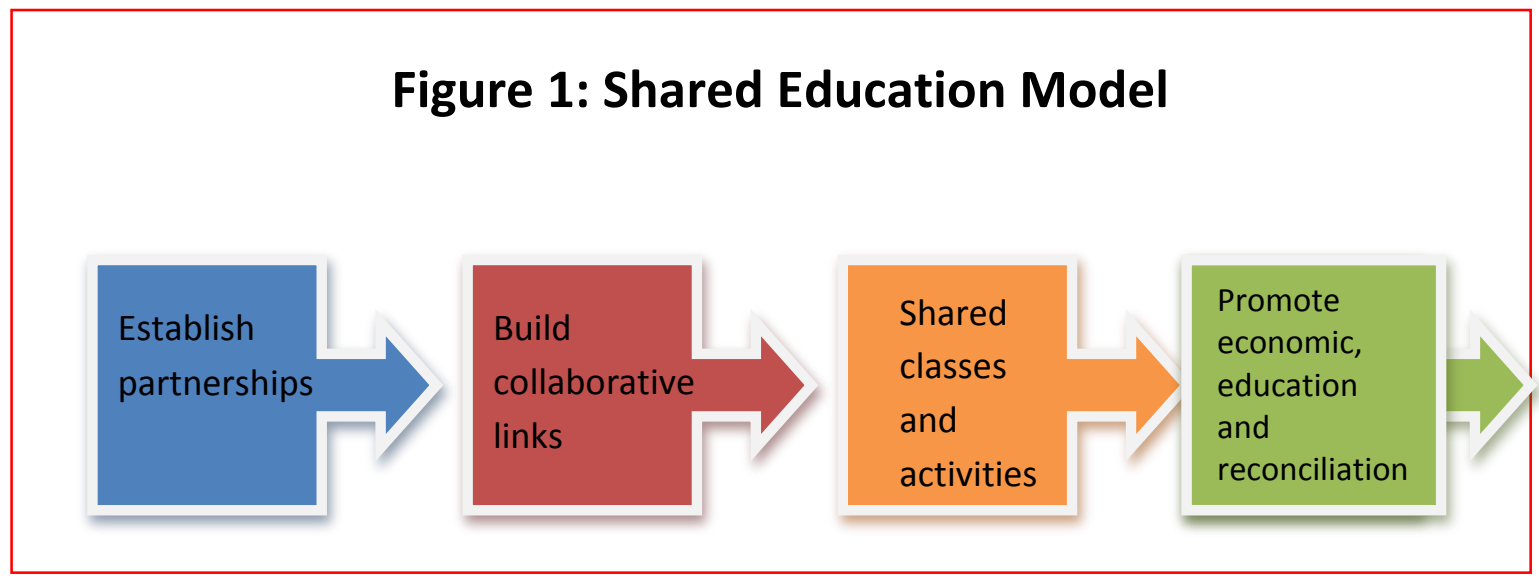

Could this model of shared education provide an alternative or a 'third way' to the separate education systems currently operating in Northern Ireland? Four years on since the inception of the SEP, this paper has three objectives. First, it analyses four post-primary partnerships (case studies), selected from the overall SEP, to estimate the costs of shared education and benefits derived by the participating children in terms of enhanced life-time income. Second, it provides a qualitative dimension to shared education by drawing out, through focus group meetings, the views of some of the teachers, parents and pupils involved in shared education. Lastly, it discusses the policy relevance of shared education at a time when key political decisions are being taken which will impact on the future of education provision in Northern Ireland. The analysis suggests that shared education could provide a 'third way' to the well-trodden paths of the two separate education systems currently operating in Northern Ireland.

\section{Returns to Education}


Sharing education confers two different types of educational benefits: education enhancement and education extension. Under enhancement, the educational experience of pupils is improved in the study of subjects they might have taken even in the absence of sharing education. This enhancement occurs through better teaching and superior facilities in the host school and a larger group of pupils with which to interact. It provides pupils with opportunities to find peers who have similar levels of academic achievement, which might be unavailable in small schools. Under extension, pupils have the opportunity of taking subjects which, in the absence of sharing education, would not have been offered to them by their parent schools.

We may analyse the benefits from sharing education in the context of individual returns to education defined as the wage premium of someone who holds that qualification over someone who does not, holding all the other educational achievements and the control variables constant. This has been the subject of extensive research both internationally and nationally. For the UK, the Institute for Fiscal Studies has computed the average wage premiums, for different qualifications, for full-time employed men and women using the 2001 Labour Force Survey, a quarterly survey of representative households in the UK (Sianesi, 2003). A salient point from this research is that, in terms of educational qualifications, a first degree yielded a return of $27 \%$ for men and $28 \%$ for women, followed by a return of $28 \%$ for men and $23 \%$ for women for 5 or more "good" $\left(A^{*}-C\right)$ GCSEs, followed by a return of $17 \%$ for men and $15 \%$ for women for two or more $A$ levels (see figure 2 ). So, young men choosing an educational route consisting of 5 or more good GCSEs (28\% premium), two or more A levels ( $17 \%$ premium), a first degree ( $27 \%$ premium), and a higher degree (14\% premium) could expect to earn $86 \%$ more than someone with no qualifications (defined as GCSES D-F). 


\section{Figure 2: Returns to Education (\%)}

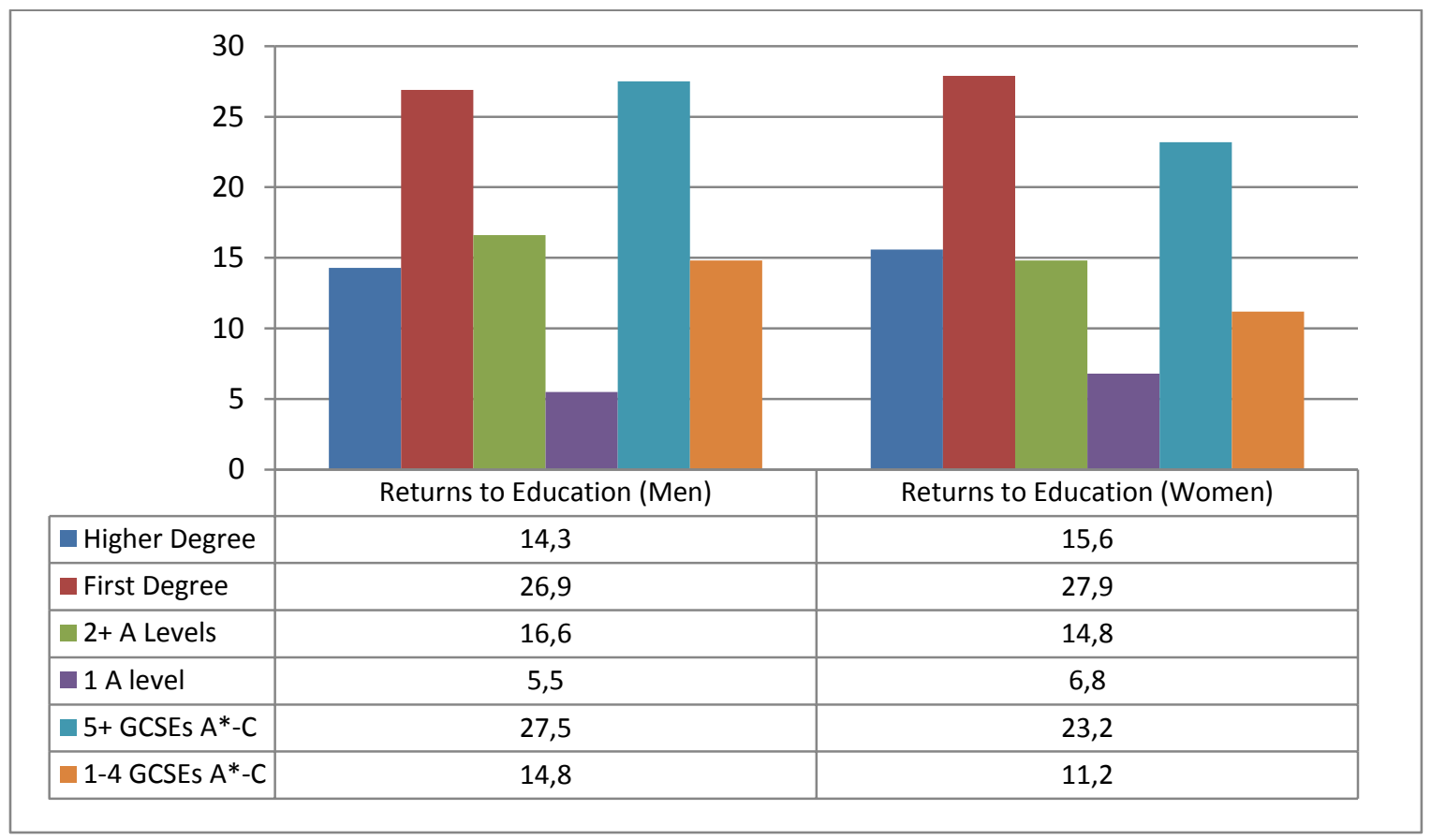

In 2009/10 there were 22,826 school leavers in Northern Ireland, Of these, 16,404, comprising $72 \%$ of total leavers, left with at least $5+$ GCSEs at $A^{*}-C$; indeed of those with at least 5+ "good" GCSEs, the overwhelming majority - 11,601 out of 16,404 or $71 \%$ - left with $3+$ A-levels and only 3,811 of the 16,404 or, $23 \%$ - left school with just 5+ "good" GCSEs. In other words, $77 \%$ of Northern Ireland pupils who achieved good GCSEs in 2009/10 progressed to A level studies and $71 \%$ of these achieved $3+A$-levels (Department of Education, 2011a).

Further up the educational chain, $82 \%$ of those with $3+$ A-levels proceeded to Higher Education and another $11 \%$ enrolled in Further Education. Consequently, there is a "cascading" effect of a good GCSE performance: 77\% of good GCSE achievers proceed to further education; $71 \%$ of these achieve $3+$ A-levels; and $82 \%$ of these proceeded to university study. Consequently, $5+$ GCSEs at $A^{*}-C$ sets the foundations of the "educational capture" of pupils.

However, at the other end of the educational spectrum, 6,422 pupils ( $28 \%$ of leavers) in Northern Ireland missed the "educational cut": 4,414 pupils who achieved only 1-4 GCSEs at 
$A^{*}-C$ level; 1,532 pupils (7\% of leavers) who while obtaining $1+$ GCSEs, did not achieve a single GCSE at $A^{*}-C$; and 476 pupils who left without any GCSEs. For such pupils, the traditional route of educational progression through sixth-form colleges and A-levels is blocked off and the only realistic options available to them are either training, on government sponsored schemes or in FE Colleges, or employment.

The causes of under-achievement embrace not only the cognitive abilities of pupils but also their home life, their primary and non-primary schooling years, the quality of teaching which motivates and kindles interest in learning (or not). Suppose, through some suitable educational intervention (in the case the SEP), the performance of 500 of the 4,414 pupils who obtained only 1-4 GCSEs at $A^{*}-C$ could be raised to $5+$ GCSES at $A^{*}-C$ grades. Then the return to education of the 500 pupils, if male, would rise from $15 \%$ to $28 \%$ and, if female, from $11 \%$ to $23 \%$. So, even if these 500 pupils left education after their GCSEs, they would see their return nearly doubled.

However, the chances are that, having achieved $5+$ GCSEs at $A^{*}-C$ grades, these 500 pupils would stay on in further education and progress to higher education. On the Northern Ireland figures: 116 (23\% of 500) would not continue to do A-levels; 355 ( $71 \%$ of 500 ) would achieve 3+ A-Levels; and, of these, 291 (82\% of 355) would progress to university leaving just 44 pupils with $3+$ A-levels following a non-university route. So, in terms of the figures shown in Figure 2, before the intervention, 500 school leavers would have seen a return of $11 \%$ (female) and $15 \%$ (male) on their education with $1+$ GCSEs at $A^{*}-C$ grade. After the intervention, 291 pupils would see a return of $66 \%$ (female) and 71\% (male) with $5+$ GCSEs at $A^{*}-C, 3+A$-levels, and a first degree.

Suppose also that because of the same intervention, 200 of the 1,532 pupils who did not achieve a single $A^{*}-C$ grade now achieved $1+$ grade at $A^{*}-C$. Then, by figure 2 , their return to education would now be $11 \%$ (female) and 15\% (male) compared to zero earlier.

In money terms, the median gross annual earnings in 2009 , for male full-time employees in Northern Ireland were $£ 24,325$ (Department of Trade, Enterprise and Investment, 2009). If we assume that a male full-time employee in Northern Ireland without any GCSEs at $A^{*}-C$ 
grades earned two-thirds of male median earnings $(f 16,217)$, then a male full-time

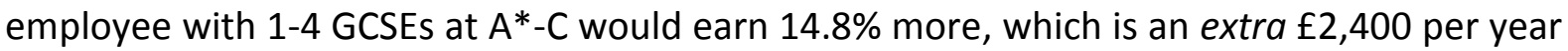
or, over a working life of 40 years, an extra $£ 96,000$. Over the 200 pupils (assume they are male) whose grades were so lifted by the intervention, this would amount to $f 19.2$ million over a 40 year working life.

The earnings of the 500 pupils whose achievements were raised from 1-4 GCSEs at $A^{*}-C$ to 5+ GCSEs at $A^{*}-C$ would be as follows for male, full-time employees:

I. For those leaving education with $5+$ GCSEs at $A^{*}-C$ (116 pupils) the gain would be $27.5 \%$ over someone with no qualifications: as our calculations show this would be an extra $£ 4,460$ per year cumulating to $£ 178,400$ over a 40-year working life. For 116 pupils, this would total $£ 20.7$ million.

II. For the 44 pupils with $3+$ A-levels not proceeding to university, the gain would be $27.5 \%+17 \%=44.5 \%$ over someone with no qualifications: this would be an extra $£ 7,217$ per year cumulating to $£ 288,680$ over a 40 -year period. For 44 pupils, this would total $£ 12.7$ million.

III. For the 291 pupils who proceeded to university (and presumably graduated), the gain would be $27.5 \%+17 \%+26.9 \%=71.4 \%$ over someone with no qualifications: this would be an extra $£ 11,578$ per year cumulating to $£ 463,120$ over a 40 -year period. For 291 pupils this would amount to $£ 134.8$ million.

We can summarise the results as follows:

a) A Year 12 (male) pupil who lifts his achievement from no GCSEs at $A^{*}-C$ grade, to 1-4 GCSEs at $A^{*}-C$ grade, will, over a working life of 40 years, see his earnings increase by $£ 96,000$ or by $£ 2,400$ annually.

b) A Year 12 (male) pupil who lifts his achievement from 1-4 GCSEs at A ${ }^{*}-C$ grade, to $5+$ GCSEs at $A^{*}-C$ grade will see his earnings increase by $£ 373,393$ less $£ 96,000=£ 277,393$ over a 40 -year period or by $£ 6,935$ annually.

Using these data we can estimate the education returns resulting from pupils participating in the Shared Education Programme - an intervention aimed at: contributing to school improvement and access to opportunity, encouraging more effective use of resources, and the promotion of social cohesion through the achievement of a shared and better society in Northern Ireland. We investigate the education returns through 4 education partnerships in the SEP with the following lead schools: Lumen Christi Grammar School ([London]Derry); Belfast High School; Belfast Model School for Girls; and Shimna Integrated College 
(Newcastle). Before considering the costs and benefits of participating in the SEP, we provide background details on the case study partnerships.

\section{Background to the Case Studies}

\section{Case Study A: Lumen Christi Partnership}

Lumen Christi (Light of Christ) was founded in 1997 as a voluntary co-educational grammar school, has a current enrolment of 850 pupils, and serves the greater (London)Derry area. Lumen Christi was designated as a Science Specialist College in 2006. The Irish News compiled a list of the 'top-performing grammar schools in Northern Ireland' (March 2011) based on those achieving 3 or more A levels at grades A-C. Lumen Christi was placed second in Northern Ireland and had previously topped the poll twice.

Lumen Christi's involvement in the SEP from 2007 has been through a project entitled Shared Learning through Science in which it acted as the lead school. The project involved two strands: first, the provision of two additional GCSE subjects for pupils from Lumen Christi and Foyle \& Londonderry College; second, the provision of weekly Key Stage 2 (KS2) science classes for four local Controlled and Maintained primary schools;

The Lumen Christi partnership with and Foyle \& Londonderry College has extended pupil choice at Key Stage 4 (KS4) by providing GCSE Engineering and Astronomy on a shared basis. Pupils attend GCSE Engineering classes twice a week at the local Further Education College, completing the course in one year. GCSE Astronomy is held on a weekly basis in Lumen Christi College. Both courses have proved popular with pupils and enhanced the educational benefits for participants from the two schools. In total over 300 pupils have gained access to key curricular subjects provided by this partnership over the last three years.

For the second strand, pupils from Long Tower and Fountain Primary Schools and Londonderry Model and Nazareth House Primary Schools are paired together for weekly KS2 Science classes at Lumen Christi College. Classes are hosted by science teachers from Lumen Christi, providing the pupils with the added benefits of specialist science provision. 
The face-to-face classes are supplemented by fortnightly video-conferencing sessions between partner primary schools.

\section{Case Study B: Belfast High School Partnership}

Belfast High School is a selective co-educational voluntary grammar school founded in 1854 . In the academic year 2010/11 it had an enrolment of 929 pupils with only $2.3 \%$ of pupils entitled to free school meals and 27 pupils with special educational needs (Department of Education: 2011a). Belfast High School was awarded specialist status in languages by the Department of Education in May 2007 ranging from the study of both Modern Foreign and Ancient Languages, to literacy in English, Mathematics and Science.

The Belfast High School partnership consists of three schools: Belfast High (lead school), Dominican College, and Hazelwood College, which have a combined pupil enrolment of 2,282 pupils. Belfast High School (41\%) and Hazelwood College (28\%) have almost twice as many pupils as Dominican College (21\%). Some 1,191 pupils were involved in the first year of SEP, representing $52 \%$ of total enrolments.

Two of the schools, Hazelwood College and Dominican College, are located in North Belfast which is considered an area of high deprivation. Belfast High School and Hazelwood are both members of the Newtownabbey Area Learning Community (ALC) and share GCSE and A-Level subjects to meet requirements under the Entitlement Framework. Dominican College had no previous relationship with the other schools beyond ad hoc events.

The partnership was provided with funding under SEP to deliver Science, Technology Engineering and Maths (STEM subjects) in 'schools in our society' project. Key Stage 3 (Years 8 - Year 10) was identified as the target group, as no collaborative or shared projects existed for these students. By delivering the programme to members of their junior schools, the partnership intended to highlight the positive impacts sharing could have on the development of the child in terms of collaboration and reconciliation. Curricular activities completed in the partnerships were: CREST (Creativity in Science and Technology awards); maths short course award; and COPE (Course in Personal Effectiveness) with STEM level 1. 
Extra-curricular activities involved: Bronze Eco-School; Robotics Challenge; and videoconferencing.

\section{Case Study C: Belfast Model School for Girls Partnership}

Belfast Model School for Girls is a Controlled secondary non-selective school with an enrolment of 930 pupils. Model schools were set up to encourage teachers to develop their skills in bringing good quality education to children. Boys and girls were always separated in Model Schools, taught in separate classes but on the same site. In 2006 Belfast Girls Model became an ICT Specialist School. At the beginning of 2010 the pupils moved into a new school building in Dunowen Gardens, Belfast which incorporates state of the art classrooms equipped with interactive whiteboards and 14 computer suites.

The SEP involved three schools in North Belfast: Belfast Model School for Girls as the lead partner working with Our Lady of Mercy Girls' School and Little Flower Girls' School. These schools are located across an area well known as being one of the worst affected by the conflict. The programme worked in two strands: in strand 1, sixth form students from the three schools met on a weekly basis to complete the COPE Course in Personal Effectiveness, worth 70 UCAS points; and, in strand 2, a larger group of students participated in full day workshops on a range of accredited vocational qualifications.

\section{Case Study D: Shimna Integrated College Partnership}

Shimna College opened in 1994 as a grant-Maintained integrated secondary school in the rural area of Newcastle Co. Down. It was designated as a Specialist School in Languages in 2006. All students study two languages from French, German, Irish and Spanish (as well as English).

The Shimna SEP has been built around some of the partnerships already formed by their specialism in languages and contains two strands. Local Controlled and Maintained primary schools are paired together so that mixed classes within each pair can receive German language teaching from Shimna staff. The venue changes on alternate weeks and, in total, eight primary schools are involved. A particular accolade for Shimna Integrated College was 
its recent success in the Times Education Supplement Outstanding Community Partnership Award (July 2011) where the judges noted:

The main hope for Northern Ireland's peaceful and prosperous future lies in its schools and the brave pioneers who are devising shared education programmes between educators in either sector. Shimna's example is at once humbling and inspirational (Ritchie, 2011:12).

Such have been the achievements of this partnership that Shimna Integrated College successfully sourced alternative funding to continue this work beyond the financial support from Atlantic Philanthropies and the International Fund for Ireland, albeit on a reduced scale.

\section{Analysis of the Costs of the Four Partnerships}

The cost calculations are based on the total number of pupil-hours (the number of pupils $\times$ the number of hours taught per pupil) delivered by each of the 4 partnerships under consideration. For the Lumen Christi partnership (Case Study: A) the total number of pupilhours delivered by the partnership grew from 5,400 in 2007-08, to 7,143 in 2008-09, to 7,796 in 2009-10, implying an annualised growth rate of $20 \%$. Taken in conjunction with the figures on staff costs, non-staff and equipment costs, the total costs movements in costs per pupil-hour are shown in see Figure 3. The cost per hour of teaching a pupil for an hour (pupil-hour) on this programme fell from an initial high of $£ 10.43$ in 2007-08 to $£ 8.93$ in 2009-10. Falling costs occur for two reasons. First, many of the equipment costs are front loaded - they are undertaken in the early years and then not repeated (except for depreciation). Second, there are economies of scale associated with the Lumen Christi programme. The sources of these economies of scale were: first, spare capacity; second, learning by doing. 
Figure 3: Per Pupil-Hour Cost Structure (f): Lumen Christi Partnership

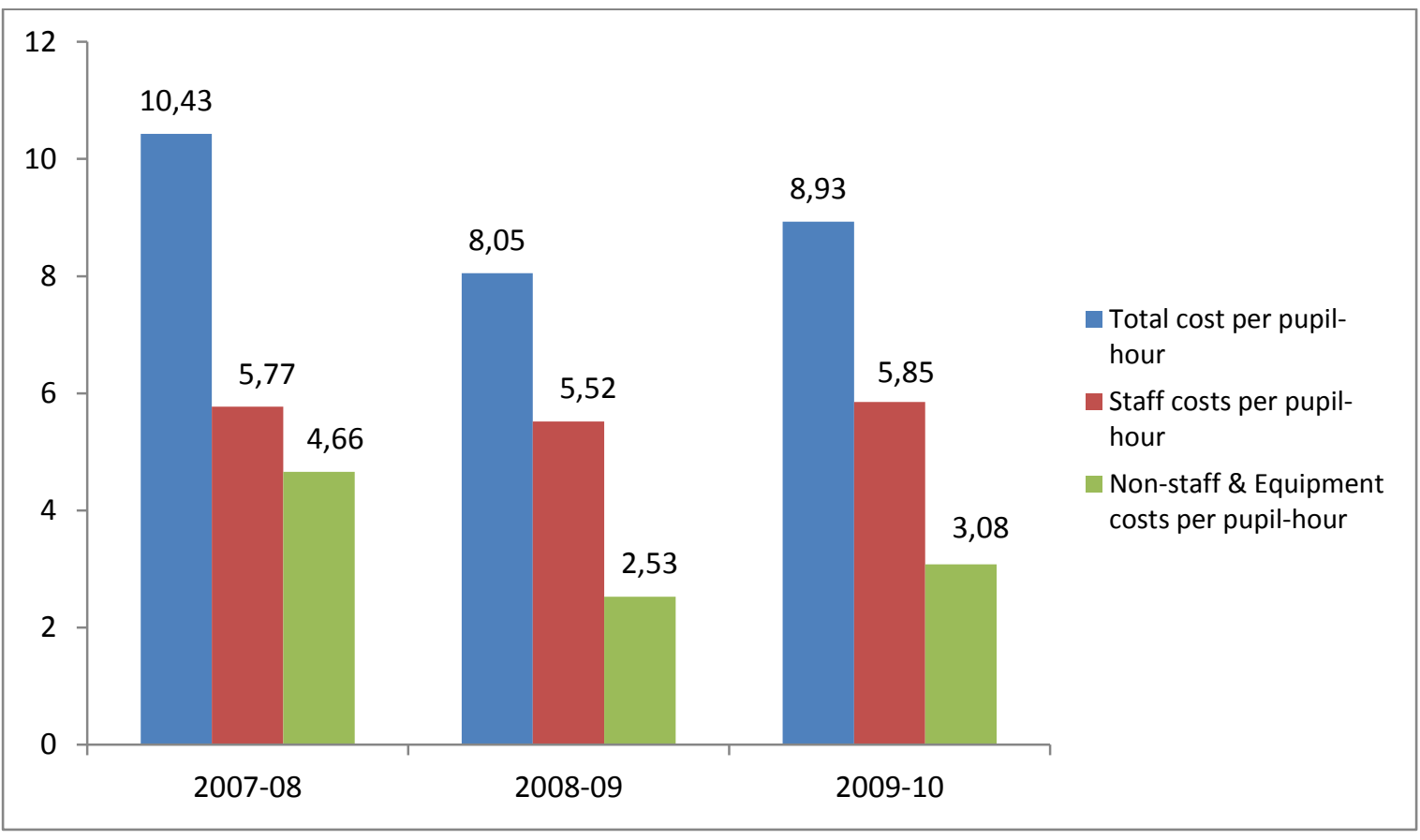

The Belfast High School partnership (Case Study: B) has been in operation for a year, $2009 / 10$. Over this year, the total number of pupil-hours delivered by the programme on curricular activities was:

I. CREST Bronze Awards: 440. These pupils received a total of 8 hours instruction over the year of which 3 were "face-to-face" hours and 5 were "virtual" hours. Thus, a total of 3,520 pupil-hours of instruction were imparted under this curricular activity.

II. Maths Short Course: 445. These pupils received a total of 6 hours instruction over the year of which 4 were "face-to-face" hours and 2 were "virtual" hours. Thus, a total of 2,670 pupil-hours of instruction were imparted under this curricular activity.

III. COPE STEM Level 1: 45. These pupils received a total of 1 hour of "face-to-face" instruction over the year. Thus, a total of 45 pupil-hours of instruction were imparted under this curricular activity.

In total, therefore, 13,950 pupil-hours were delivered by the programme on curricular activities. In addition, a number of pupils received instruction in extra-curricular activities: 24 pupils each received an hour's face-to-face instruction towards the Eco-schools award and 45 pupils each received an hour's face-to-face instruction in web design. So, aggregating over curricular and non-curricular activities, the Belfast High programme delivered a total of 14,019 pupil-hours with a cost structure shown in Figure 4. 


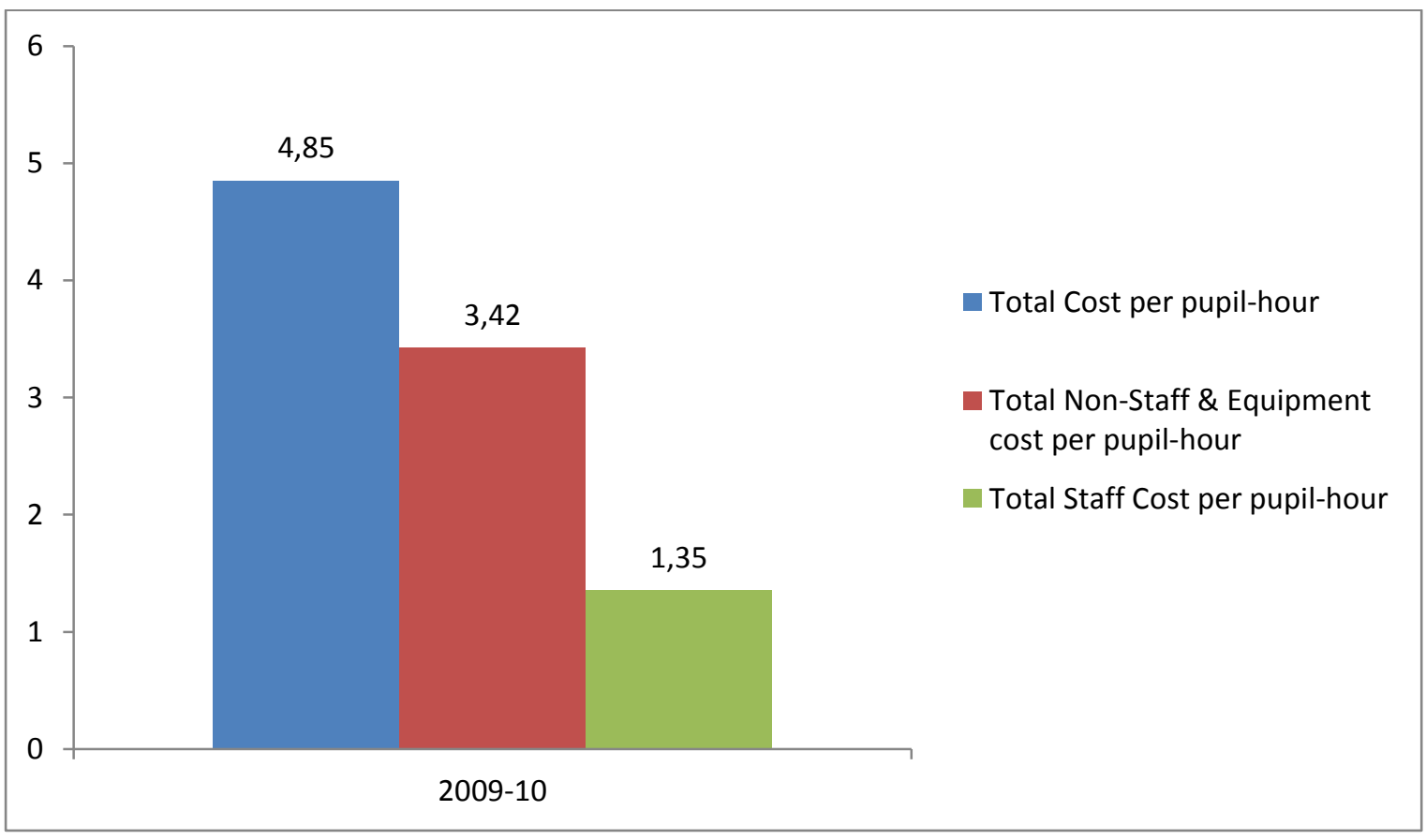

Over the period of the Belfast Girls Model School partnership (Case Study: C), the number of pupils on Strand 1 of the programme increased from 30 in 2007-08, to 45 in 2008-09, falling to 32 in 2009-09. Over this period, total pupil-hours rose from 870 in 2007-08 to 1,395 in 2008-09 before falling to 864 in 2009-10. Over the same period, the number of pupils on Strand 2 of the programme stayed at 60 in each of years 2007-08, 2008-09, 200910 with pupil-hours of, respectively, 180, 180, and 120.

Figure 5 shows the costs per student-hour for both strands of the project distinguishing between staff and non-staff costs. Non-staff and equipment costs for Strand 2 activity, per Strand 2 pupil, were: $£ 96$ in 2007-08, $£ 70$ in 2008-09 and $£ 110$ in 2009-10; and per Strand 2 pupil-hour of: $£ 31.91$ in $2007-08, £ 23.26$ in $2007-08$, and $£ 55.00$ in $2009-10$. On the other hand, equipment costs could be entirely associated with Strand 1 activity. Consequently, non-staff and equipment costs for Strand 1 activity, per Strand 1 pupil, were: $f 95$ in 2007$08, £ 317$ in $2008-09$ (when $£ 6,345$ worth of equipment was bought), and $£ 348$ in 2009-10 (when another $£ 2,668$ worth of equipment was bought). The corresponding per-pupil-hour figures were $£ 3.27$ in 2007-08, $£ 10.23$ in 2008-09, and $£ 16.92$ in 2009-10 (see figure 5). 
Figure 5: Staff and Non-staff Costs per Pupil-Hour (f): Belfast Model Girls School Partnership

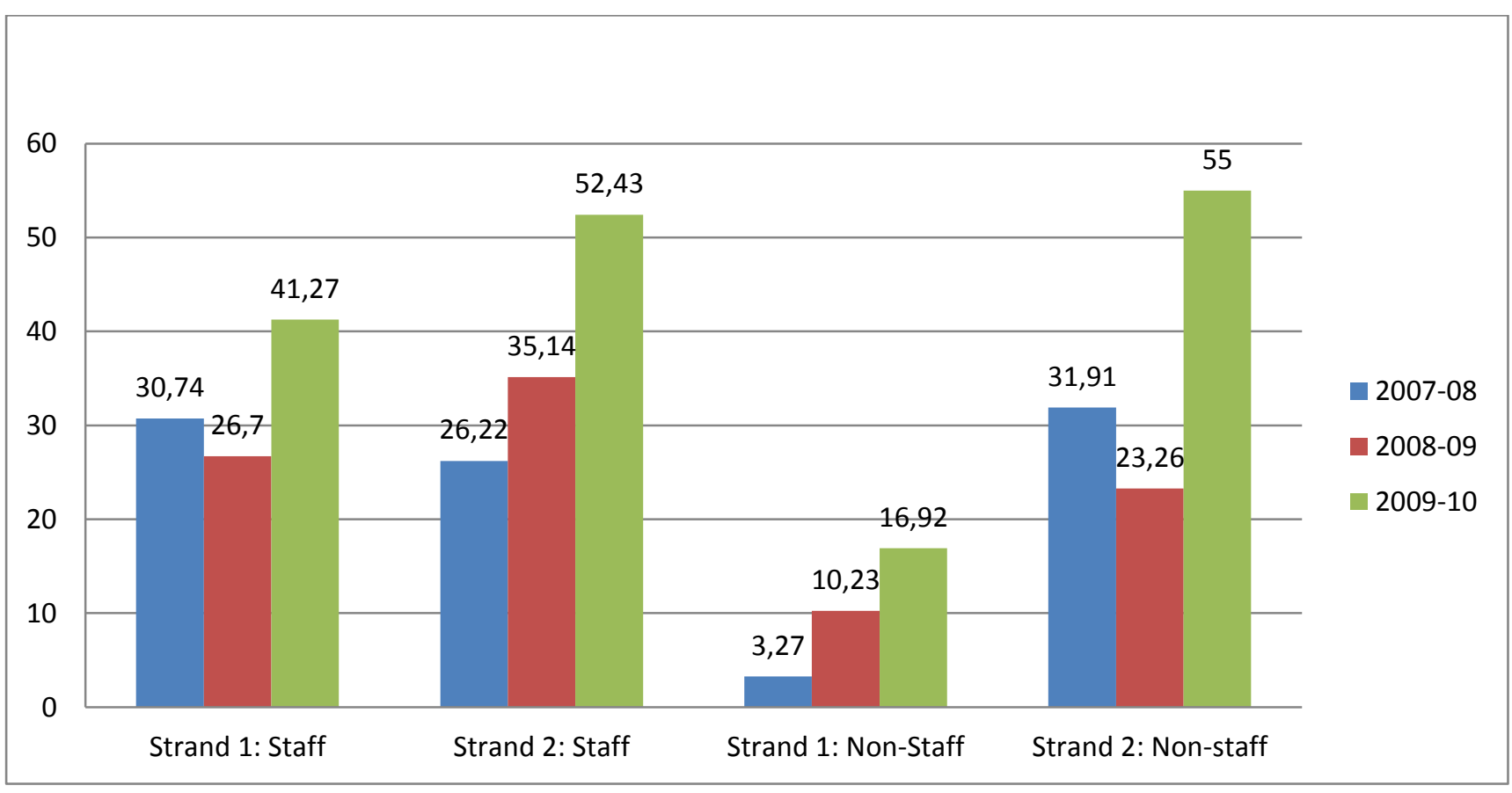

Over the period of the Shimna Integrated College partnership (Case Study: D), the number of pupils served by the partnership increased from 156 in 2007-08 to 231 in 2008-09 to 232 in 2009-10, representing an annualised growth rate of $22 \%$. Simultaneously, the number of pupil-hours delivered by the programme increased from 2,984 in 2007-08 to 3,535 in 200809 to 6,266 in 2009-09 representing an annualised growth rate of 45\%. Figure 6 shows the structure of costs of the Shimna partnership.

It should be pointed out the Shimna partnership is a larger and more complex project than the three analysed earlier. First, it involves 10 schools and 230 pupils with five pair-wise school partnerships. This leads to formidable logistical difficulties in terms of timetabling and classrooms. Second, given the nature of the partnership, both the teacher and the pupils have to travel. Pupils in one school travel to the other school in their partnership and the teacher travels from Shimna Integrated College to the school where the classes are to be held. Since, for the teacher, travel time has to be added to instructional (and lesson preparation) time, the partnership is expensive in terms of staff costs. It is also expensive in terms of pupil transportation costs since a relatively large body of students are transported 
in a rural setting lacking the public transport facilities of, say, Belfast or (London)Derry. We now quantify the benefits associated with activities of the four partnerships.

\section{Figure 6: Per Pupil-Hour Cost Structure (f): Shimna Integrated Partnership}

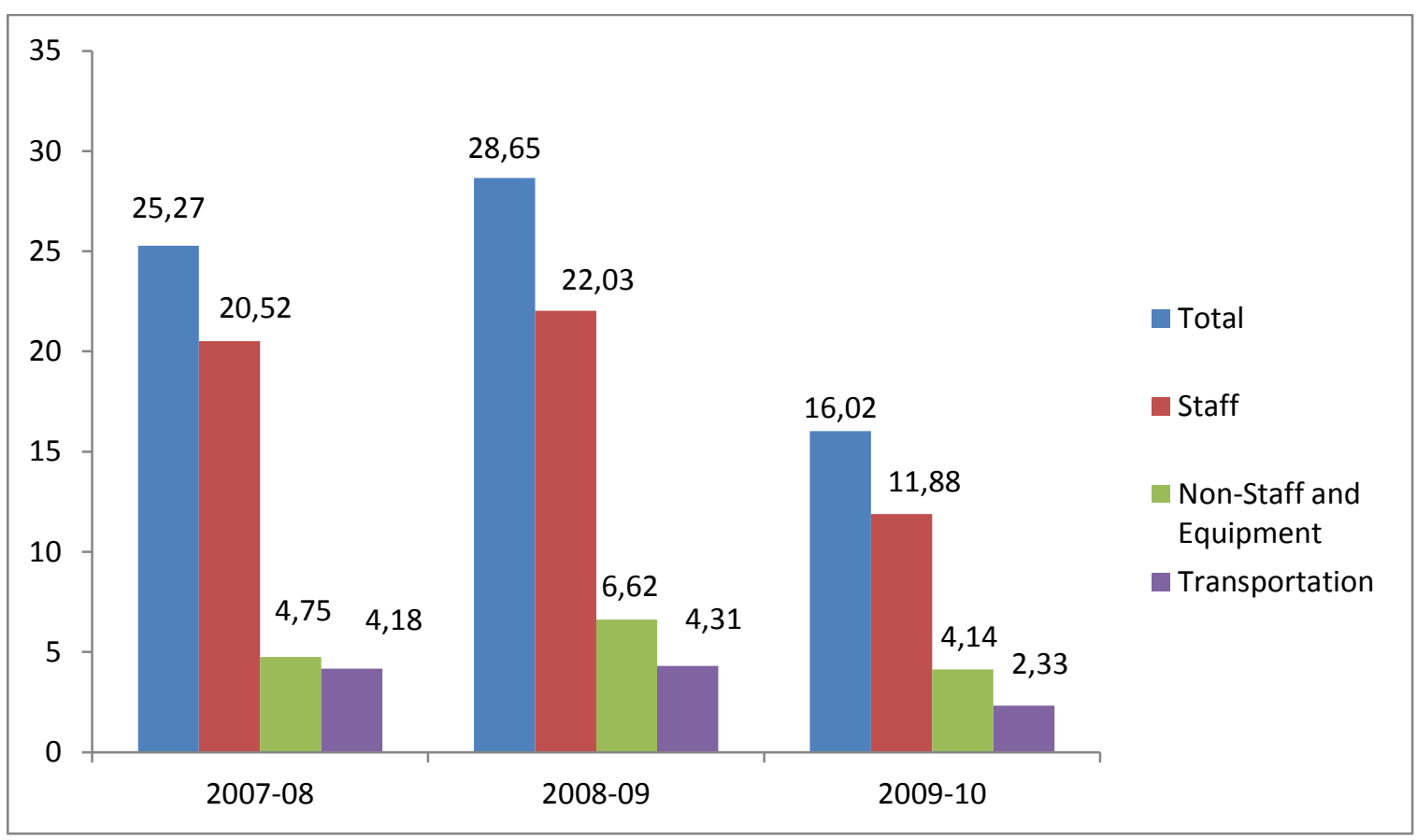

\section{Analysis of Benefits of the Partnerships}

The Lumen Christi partnership offers both enhancement and extension types of benefits (discussed earlier). For the 88 pupils from the four primary schools - Long Tower and Nazareth House (both Maintained) and Londonderry Model and Fountain (both Controlled) it afforded, in 2009-10, the opportunity to undertake enhanced studies in Biology/Chemistry and Physics in mixed groups. For the 83 post-primary students from Foyle and Lumen Christi it extended education by offering the opportunity to study subjects (again in mixed groups), like Engineering and Astronomy, which did not feature on the curriculum of either college. Over the three years that the partnership has been in existence, 214 primary pupils have received enhanced education and 154 post-primary pupils have expanded their subject range through the Lumen Christi partnership.

In order to quantify these benefits, we assume that instead of $5+$ GCSEs at $A^{*}-C$ grades they might have obtained through the Lumen Christi partnership, 20 pupils of the 214 pupils 
who participated (less than $10 \%$ of the total) would have obtained $1-4$ GCSEs at $A^{*}-C$ grades through studying at their own schools. Then as, the analysis on education returns (above) shows, each of these 20 pupils whose performance was lifted to $5+$, from $1-4$, GCSEs at $A^{*}-C$ grades would see their working life earnings increase by $£ 277,393$. Summed over 20 pupils, this amounts to an increase in total working-life earnings of $f 5.5$ million. Given that the cost per pupil is $£ 1,200$ over three years, the benefit-cost multiplier $(£ 277,393 / £ 1,200)$ is 231 : every $f 1$ in expenditure on SEP produces $£ 231$ in benefits.

The analysis is similar for education extension. Neither Lumen Christi nor Foyle College were in a position to offer either Engineering or Astronomy as GCSE subjects to their pupils: the numbers were simply too small to make such courses sustainable. But when the two schools came together, class sizes became viable: 16 students studied for a one-year GCSE in Engineering in Year 1 of the programme ( 8 from Foyle) rising to 29 by Year 3; 20 students enrolled for a two-year course in Astronomy.

Suppose the likelihood of all 29 pupils receiving $5+$ GCSEs at $A^{*}-C$ grades was $60 \%$ in the absence of the partnership but rose to $80 \%$ after the partnership had been established. Then the expected extra earnings over a 40-year working life of each of these 29 pupils would rise from $£ 166,436(£ 277,393 \times 0.6)$ to $221,914(£ 277,393 \times 0.8)$ representing an expected boost of $£ 55,478$. Over 29 pupils, these aggregate to $£ 1.6$ million.

Taking into account both primary and post-primary students, the Lumen Christi partnership, in its entirety, could deliver benefits, defined as the increase in the working-life earnings of the pupils on the programme, of $f 7.1$ million. Of this, $f 5.5$ would derive from the partnership with primary schools and $£ 1.6$ million from the partnership with Foyle College.

As a consequence of the Belfast High School partnership, approximately 450 year old pupils, aged 11-16, in Northern Ireland had their abilities in Science, Technology, Engineering, and Mathematics (STEM) subjects enhanced through this training. Suppose that this intervention helped $10 \%$ of these students (45 pupils) achieve $5+$ GCSEs at $A^{*}-C$ grades. Of the remaining $90 \%$, some would have achieved $5+$ GCSEs at $A^{*}-C$ grades anyway, though with a greater likelihood of achievement consequent upon the intervention; the 
others would not have achieved $5+$ GCSEs at $A^{*}-C$ grades even with the assistance of the SEP intervention.

Then on this paper's calculations, each of the affected 45 pupils would receive, following the intervention, a boost in working-life earnings of $£ 277,393$, totalling $£ 12.5$ million. These would represent the benefits to the pupils over their working lives delivered by the Belfast High partnership.

The Belfast Model Girls Partnership confers two very different types of benefits: to the more "able" pupils (Strand 1), it delivers a Certificate in Personal Effectiveness (CoPE) which is worth 70 UCAS points in some universities; to the less "able" students (Strand 2), it delivers an industry-level vocational qualification. In doing so, there is clearly a trade-off: the CoPE qualifications, though more useful, is delivered at a per-pupil cost between 5-7 times the cost of the vocational qualification.

Strand 1 pupils were Sixth Form pupils and benefited from the 70 UCAS points that some universities offered those with CoPE qualifications. On the assumption that, aided by these points, six of the 32 pupils on the programme went to university (and stayed on to get a degree) then this would raise each of these pupils' working-life earnings by $27 \%$ (the premium associated with a first degree) above that of a non-graduate. On our calculations, using 3 A-levels as a comparator, this would deliver to each of these six pupils' additional working-life earnings of $£ 174,440$, totalling $£ 1.05$ million.

Strand 2 pupils, who were offered a more vocational route, might have been expected to leave school without any GCSE passes at $A^{*}-C$ level. It is possible that the intervention tightened the connection between pupil and school, instilled in them an interest in career, if not in learning, and thereby ensured that, say, one-third of the 60 pupils on Strand 2 programme achieved 1-4 GCSEs at $A^{*}-C$ grades. This would mean that 20 pupils would experience a rise in working-life earnings of $£ 96,000$. Aggregated over 20 pupils, Strand 2 would deliver total benefits in the form of increased working-life earnings of $£ 1.92$ million. Both strands, taken in their entirety, would deliver benefits of $£ 2.97$ million through increased earnings of the pupils on the two programme strands. 
The value of the Shimna Integrated College partnership should be assessed against the background of the poor foreign language skills of British and Irish teenagers (and adults). By providing 104 hours of specialist teaching in German to 230 primary school pupils at a cost of around $£ 400$ per pupil, it attempts to redress a fundamental educational problem in the UK for a price of $£ 16$ per pupil-hour. Not only that: the study of German extends beyond language teaching to encompass German culture and philosophy and also issues related to divided societies in Northern Ireland and abroad.

We assume ceteris paribus that $10 \%$ of the Shimna partnership pupils are sufficiently motivated and interested to subsequently become fluent in another language and to move to mainland Europe in search of a job. We assume that offers them a premium of $15 \%$ over the Northern Ireland median annual earnings of $£ 24,325$ for males in full-time employment. This amounts to $£ 3,649$ annually or $£ 138,760$ over a 40 year working life. Aggregated over 23 pupils this yields a total benefit of $£ 3.2$ million pounds of their collective working lives.

Table 1 sets our estimates of the total economic benefits emanating from the four partnerships discussed above. These benefits are defined in terms of the increased earnings of pupils who have benefited from the shared education intervention. Aggregating these per-pupil benefits over the total number of pupil beneficiaries obtains the economic benefit of the four partnerships. Table 1 suggests that the total net benefit, aggregated over the four partnerships, amounted to over $£ 23$ million. This figure was obtained as the annual increase in the working life earnings per pupil beneficiary of the SEP intervention $\times$ the number of beneficiary pupils $\times 40$ years working life. 
Table 1: Analysis of Benefits across the 4 SEP partnerships

\begin{tabular}{|c|c|c|c|c|c|c|}
\hline & \multicolumn{2}{|c|}{ Lumen Christi } & \multirow[t]{2}{*}{$\begin{array}{l}\text { Belfast } \\
\text { High }\end{array}$} & \multicolumn{2}{|c|}{ Belfast Model } & \multirow[t]{2}{*}{ Shimna } \\
\hline & Primary & $\begin{array}{l}\text { Post- } \\
\text { Primary }\end{array}$ & & Strand 1 & Strand 2 & \\
\hline Benefit & $\begin{array}{l}\text { Some } \\
\text { students } \\
\text { will get } \\
\text { good } \\
\text { GCSEs }^{*}\end{array}$ & $\begin{array}{l}\text { Likelihood } \\
\text { of good } \\
\text { GCSEs is } \\
\text { increased }\end{array}$ & $\begin{array}{l}\text { Some } \\
\text { students } \\
\text { will get } \\
\text { good } \\
\text { GCSEs }^{2}\end{array}$ & $\begin{array}{l}\text { Some } \\
\text { students } \\
\text { will go to } \\
\text { university } \\
\text { using } 70 \\
\text { UCAS } \\
\text { points }\end{array}$ & $\begin{array}{l}\text { Some } \\
\text { students } \\
\text { will } \\
\text { achieve 1- } \\
4 A^{*} \text {-C } \\
\text { GCSE } \\
\text { grades }\end{array}$ & $\begin{array}{l}\text { Some } \\
\text { students will } \\
\text { gain fluency } \\
\text { and seek } \\
\text { work in } \\
\text { mainland } \\
\text { Europe }\end{array}$ \\
\hline $\begin{array}{l}\text { Pupils } \\
\text { benefitting }\end{array}$ & $\begin{array}{l}20 \text { out of } \\
214\end{array}$ & $\begin{array}{l}\text { Likelihood } \\
\text { for all } 29 \\
\text { pupils } \\
\text { raised } \\
\text { from } 60 \% \\
\text { to } 80 \%\end{array}$ & $\begin{array}{l}45 \text { out of } \\
214\end{array}$ & $\begin{array}{l}6 \text { out of } \\
32\end{array}$ & $\begin{array}{l}20 \text { out of } \\
60\end{array}$ & 23 out of 231 \\
\hline $\begin{array}{l}\text { Amount of } \\
\text { benefit per } \\
\text { pupil over } \\
40 \text { year } \\
\text { working- } \\
\text { life }\end{array}$ & $£ 277,393$ & $\begin{array}{l}£ 55,478 \\
\text { rise in } \\
\text { expected } \\
\text { earnings }\end{array}$ & f277,393 & $£ 174,440$ & $£ 96,000$ & $£ 138,760$ \\
\hline $\begin{array}{l}\text { Total } \\
\text { Benefit }\end{array}$ & $\begin{array}{l}f 5.5 \\
\text { million }\end{array}$ & $\begin{array}{l}\text { f1.6 } \\
\text { million }\end{array}$ & $\begin{array}{l}\text { f12.5 } \\
\text { million }\end{array}$ & $\begin{array}{l}\text { f1.1 } \\
\text { million }\end{array}$ & $\begin{array}{l}\text { f1.9 } \\
\text { million }\end{array}$ & £3.2 million \\
\hline $\begin{array}{l}\text { Total } \\
\text { Project } \\
\text { Cost over } \\
\text { life of } \\
\text { project }^{3}\end{array}$ & f1.8 million & & $f 67,926$ & $£ 126,479$ & $£ 34,440$ & $£ 277,144$ \\
\hline $\begin{array}{l}\text { Total Net } \\
\text { Benefit } \\
\text { over } 40 \\
\text { year } \\
\text { working- } \\
\text { life }\end{array}$ & f5.3 million & & $\begin{array}{l}\text { f12.4 } \\
\text { million }\end{array}$ & $£ 973,521$ & $\begin{array}{l}\text { £1.87 } \\
\text { million }\end{array}$ & f2.9 million \\
\hline
\end{tabular}

\footnotetext{
${ }^{2}$ The assumption is that they will achieve $5+$ GCSEs at $A^{*}-C$ after the SEP intervention, instead of 1-4 A*-C in its absence

${ }^{3}$ Lumen Christi: $£ 56,344, £ 57,483$, and $£ 69,679$ for, respectively, 2007-08, 2008-09, 2009-10.

Belfast Model (S1): $£ 29,610, £ 50,085$, and $£ 46,784$ for, respectively, 2007-08, 2008-09, 2009-10.

Belfast Model (S2): $£ 10,500, £ 11,040$, and $£ 12,900$ for, respectively, 2007-08, 2008-09, 2009-10.

Shimna: $£ 75,404, £ 101,329$, and $£ 100,411$ for, respectively, 2007-08, 2008-09, 2009-10.
} 


\section{Teachers, parents and pupils}

What do teachers who deliver shared education, pupils who participate, and parents who agreed to their children's involvement think about shared education? Using data gathered in the case study schools we address this question and articulate the qualitative benefits of the SEP. A key issue raised by teachers delivering the SEP was the need for leadership from school managers and senior staff across the partnership. Unless there was explicit support and endorsement from education managers for what the programme sought to achieve then teachers felt 'abandoned to yet another initiative'. One Principal argued strongly for the inclusion of SEP in the school development plan as a demonstration of the commitment by senior staff and a signal to all teachers that it was an important priority for the school. The question of leadership however extended beyond a commitment by school managers. Some school principals commented on the need for political leadership providing the right context in which sharing in education could flourish. Teachers were candid in their assessment of the existing segregated system of education:

It's hard to believe that I had never been inside the door of other schools within a mile of my own school. SEP has changed all that. We have established lasting friendships with teachers from the Controlled sector. Apart from the huge benefits for our children... I now know these people not only as my professional colleagues but also my friends and feel that I can lift the phone at any time for advice and to explore opportunities to work together (Teacher).

If leadership at school and political levels was deemed important, this was particularly true of parents whose children participated in the shared education programme. Some teachers argued that the biggest challenge they faced was in bringing the families and wider communities with them on the shared education journey. Hence, schools made concerted efforts to keep parents fully informed about the programme, put on showcase events to celebrate the work of their partnerships, and invited parents from both communities to their open nights and prize giving. All of this was aimed at challenging parental perceptions that their children would be treated differently in a Controlled or Maintained school and should sectarianism in whatever form occur, it would not be tolerated. Isolated sectarian incidents were firmly dealt with and this sent a clear message to the pupils directly involved, parents and the wider school community. One school Principal made the point that SEP could only progress at a pace acceptable to parents. In cases where some of those parents 
were 'hardliners', schools needed to be careful that they were not pushing too far ahead of the more entrenched attitudes however much they disagreed with such diehards in an era of political change. As one parent with a known paramilitary background put it: 'I don't know why or what I was worried about 'cause shared education is opening my eyes about them ones'.

Teachers were particularly adept at weaving the theme of reconciliation into curriculum delivery or 'tackling the elephant in the room syndrome' as one described it. Although there was an acceptance that not every teacher felt comfortable or experienced to do this.

We are not suggesting that every lesson should include some element of community relations. It is hard, for example, to see how it could feature in maths. On the other hand, teaching languages offers the ideal opportunity to explore cultural differences - the celebrations around the fall of the Berlin wall and some reflection on why we have 'peace' walls in Northern Ireland is a case in point. In other words, when the opportunity arises to talk about differences we shouldn't avoid it - create an awareness of difference and celebrate, let's not pretend it doesn't exist (Teacher).

The achievements of schools varied depending on their starting point. One partnership offered a simple example of impact as the symbolism of having children wearing different school uniforms in their school. While this may seem fairly trivial, for the schools concerned which are located in a hugely fractured city (London)Derry, it was very significant. Crossing physical boundaries to get to each other's schools amounted to transcending long established cultural barriers. Teachers explained that aside from the substantive activities that their pupils engaged in, SEP has challenged preconceived views about whether pupils would be safe and secure in 'the other school'. Both schools involved in this exchange worked hard to extend friendships to the parents of these children, some of whom were fascinated to see the inside of a Controlled or Maintained school. As one parent pointed out: 'when you think about it, the children have been trail-blazers. They have paved the way for us as parents to cross physical boundaries that we wouldn't normally countenance. They have provided us with the necessary reassurance.'

Several front-line teachers summarised what they considered to be the ultimate impact on children involved in SEP, best expressed by one teacher: 
The impact of SEP is that it gives our kids an ongoing cross-community opportunity to meet regularly, to get to know each other, and to lift the clouds of suspicion that may have existed. They now believe that it is okay to be different and that it is okay to be yourself. I am convinced that those involved in the programme will be more likely to challenge prejudices either in their homes or beyond (Teacher).

The spill-over effects into the community were considered significant. As one School Principal put it: 'the lasting effect of this is not just through the school but also out in the community. You will reach a point when so many classes are collaborative that people around here will have gone to school with each other regardless of their religion'. Teachers also highlighted the many common issues that young people face regardless of the community background which SEP could build on. Young people, for example, face pressures around drugs, alcohol and social relationships. These issues transcend religious identity and can become a unifying platform to develop trust between pupils and a foundation for exploring more sensitive issues.

Other teachers were much more explicit about the direct educational benefits of SEP arguing that it improved the quality of education for participating pupils by providing wideranging curricular courses.

SEP has had a very direct educational benefit. I don't see the point otherwise. It adds value to what is already delivered through the A-level and AS-Level syllabus. The classes that supported mainstream subjects such as English, Science and Biology were very good and the results should be reflected in the pupils' grades. Similarly, there were some classes on specific software, e.g. AutoCAD aimed to support children in their coursework (Teacher).

For pupils, their experiences tended to centre on the opportunity to meet young people from other schools and make new friends. This included developing friendships originating in shared education classes outside of school through social media outlets. Part of this experience was to see inside each other's school or as one pupil put it: 'I did a double-take when I saw all the religion statutes of Our Lady, God and that but then I'm sure they found photos of the Queen and all in our school a bit weird'. What was particularly salient however was the indifference, verging on apathy, which many pupils displayed on the topic of religion, typical of which was the comment: 'It doesn't make a difference to me, I don't care what religion others are. It might be good to understand, but I am not very interested' 
and 'I don't pick friends by religion - I pick them by personality like if they are bright, funny and just a good friend'.

\section{Conclusions}

What are the potential policy implications arising from this research? The findings of this work could contribute to an emerging policy debate about how best to structure the future of education in Northern Ireland. In September 2011, the Minister of Education (Sinn Féin's John O'Dowd) launched an education policy paper entitled Putting Pupils First: Shaping our Future - The Next Steps for Education in which he notes the excess of school places due to the demographic down-turn (some 85,000 spare places - the equivalent of 150 schools). Therein the Minister highlights the need for partnership working across religious boundaries with the needs of children and young people placed as the centre of a proposed strategic planning exercise of the education estate. He commissioned the Education and Library Boards and the Council for Catholic Maintained Schools (CCMS) to conduct viability audits of all schools in Northern Ireland followed by a strategic review to shape the future of education delivery. The terms of reference for the strategic planning exercise calls for 'realistic, innovative and creative solutions to address need, including opportunities for shared schooling on a cross-sectoral basis' (Department of Education, 2011c: 2). In addition, the draft Programme for Government 2011-15 includes policy commitments to shared education as follows: (i) establish a Ministerial advisory group to explore and bring forward recommendations to the Minister of Education to advance shared education; and (ii) ensure all children have the opportunity to participate in shared education programmes by 2015 and substantially increase the number of schools sharing facilities by 2015 .

A policy window therefore exists to embed shared education through a structural reconfiguration of the schools estate in Northern Ireland, the result of which will be a more efficient system of education with fewer teachers but one which confers education and reconciliation benefits on its pupils, as evidenced in this research. This, in turn, will contribute to the wider goals of the devolved government in creating a more cohesive society. The challenge however is that education officials appear not to fully appreciate the education and reconciliation benefits associated with shared education and eschew the 
opportunity for shared solutions. Their preferred option is to close schools below certain arbitrary threshold enrolment levels and retain fewer but larger schools - a rationalisation process which would take place within two separate school estates and result in the maintenance of the segregated status quo. In short, a macro 'solution' which takes no cognisance of how these changes will impact on communities, particularly in rural areas where the closure of a local Maintained or Controlled school could signal the exodus of Catholics or Protestant parents and their children, polarising Northern Ireland even further.

An alternative micro or locally based option is proposed, based on the research in this paper where schools from different sectors explore shared education 'solutions'. Shared education makes existing boundaries between schools of different management types much more porous without challenging parent/pupil cultural identities. This is quite different from integrated education where loss of identity is seen as a sine qua non and is yet another sector competing for a diminishing number of pupils. In a period of budget retrenchment shared education offers politicians an opportunity to mitigate against the worst cull of schools proposed by education officials. Shared 'solutions' are therefore more politically palatable and could avoid 'save our school' campaigns (e.g. parents chaining themselves to school railings). Shared education can develop at a pace consistent with parental aspirations and could evolve to meet the First Minister's goal of a unified education system in Northern Ireland. The budgetary 'crisis' therefore offers an opportunity for politicians to respond positively to the community momentum for change where shared curriculum provision is not only good in terms of education returns but can also contribute to a more reconciled Northern Ireland. 


\section{References}

Bain Report (2006) Schools for the Future: Funding, Strategy and Sharing. Belfast: Independent Strategic Review of Education.

Brocklehurst H, 2006 Who's Afraid of Children? Children, Conflict and International Relations (Aldershot: Ashgate)

Community Relations Council (2009) Towards Sustainable Security: Interface Barriers and Legacy of Segregation in Belfast. Belfast: Community Relations Council.

Department of Education (2011a) School Statistics 2010/11 accessible at: http://www.deni.gov.uk/index/32-statisticsandresearch pg.htm

Department of Education (2011b) Community Relations, Equality and Diversity in Education. Bangor: DE.

Department of Education (2011c) Area Planning - Terms of Reference Putting Pupils First. Bangor: Department of Education Northern Ireland.

Department of Trade, Enterprise and Investment (2009) Northern Ireland Annual Survey of Hours and Earnings. Belfast: DETI.

Donnelly, C. and Hughes, J. (2006) 'Contact, culture and context: evidence from mixed faith schools in Northern Ireland and Israel' Comparative Education 42(4) 493 - 516

Gallagher. T. (2004) Education in Divided Societies (London: Palgrave/Macmillan).

Gallagher, T., Stewart, A., Walker, R., Baker, M. and Lockhart, J. (2010) 'Sharing education through schools working together' Shared Space, Issue No. 10: 65-74. Belfast: Community Relations Council

Hayes, B. and McAllister, I. (2009) 'Education as a mechanism for conflict resolution in Northern Ireland' Oxford Review of Education, 35(4) 437-450. 
Hughes, J. (2007) 'Mediating and moderating effects of inter-group contact: case studies from bilingual/bi-national schools in Israel' Journal of Ethnic and Migration Studies 33(3) 419 $-437$

Hughes, J., Donnelly, C., Gallagher, T., Carlisle, K., (2010) School Partnerships and Reconciliation: an evaluation of school collaboration in Northern Ireland. Belfast: Queen's University, School of Education.

Hughes J, (2011) 'Are Separate Schools divisive? A Case Study from Northern Ireland' British Educational Research Journal 37(5) 829-850.

Knox, C. (2011) 'Cohesion, Sharing and Integration in Northern Ireland' Government and Policy: Environment and Planning C 29 (3), 2011, pp. 548 - 566.

Northern Ireland Executive (2011) Draft Programme for Government 2011-15 - Building a Better Future. Belfast: OFMdFM.

O’Dowd, J. (2011) Putting Pupils First: Shaping Our Future - The Next Steps for Education. Bangor: Department of Education Northern Ireland.

Office of the First Minister and deputy First Minister (2010) Programme for Cohesion, Sharing and Integration: Consultation Document. Belfast: OFMdFM.

Police Service of Northern Ireland (2011) Security situation statistics: available at: http://www.psni.police.uk/index/updates/updates statistics.htm

Ritchie, M. (2011) 'A Bridge across the River Foyle' Times Education Supplement: $10-17,8^{\text {th }}$ July 2011.

Robinson, P. (2009) 'Making Devolution Work' speaking at the Ulster Hall, Belfast $8^{\text {th }}$ September: available at: http://www.dup.org.uk/default.htm

Robinson, P. (2011) 'I want to see a shared and united society'. Speech delivered at Down High School, 31 $1^{\text {st }}$ March 2011. 
Sianesi, B. (2003) Returns to Education: A Non-technical Summary of the Centre for the Economics of Education Work and Policy Discussion. London: Institute of Fiscal Studies available at: http://www.ifs.org.uk/docs/cee summ.pdf 